\title{
Azygos lobe: A rare case
}

\author{
Azigos lob: Nadir bir olgu \\ Mustafa Korkut $(\mathbb{D}$, Yusuf Karanci $(\mathbb{D}$, Murat Duyan $\mathbb{D}$ \\ Department of Emergency Medicine, Health Science University, Antalya Training and Research Hospital, Antalya, Turkey
}

\begin{abstract}
Azygos lobe is a rare congenital variation usually located in the right lung and more common in males. Although it is asymptomatic and does not require special treatment, it should always be considered in the differential diagnosis of lung lesions. In this article, we report a 52-year-old male patient who was admitted to the emergency room with trauma and computed tomography revealed azygos lobe.

Keywords: Azygos lobe, computed tomography, emergency department
\end{abstract}

$\ddot{O Z Z}$

Azigos lobu, nadir görülen doğumsal, sıklıkla sağ akciğer yerleşimli ve erkeklerde daha yaygın bir varyasyondur. Asemptomatik olasına ve özel bir tedavi gerektirmesine rağmen , akciğer lezyonlarının ayıııcı tanısında her zaman göz önünde bulundurulmalıdır. Bu yazıda acil servise travma ile başvuran ve bilgisayarlı tomografide azigos lobu saptanan 52 yaşında bir erkek hasta, sunuldu.

Anahtar sözcükler: Azigos lobu, bilgisayarlı tomografi, acil servis.

Azygos lobe is a rare congenital anomaly in the upper lobe of the right lung, and is present in $0.2-1.2 \%$ of the general population. ${ }^{[1,2]}$ In the intrauterine period, the azygos vein extends anteriorly over the lung, situated over the right upper apical lobe or posterior segment. Like other congenital anomalies of the lung, it is asymptomatic and does not require any treatment. ${ }^{[3-5]}$ In this case report, we aimed to discuss the subject with regards to the literature in order to make the differential diagnosis by recognizing the azygos lobe of the physicians.

\section{CASE REPORT}

A 52-year-old male patient was admitted to the emergency department with head and chest pain after falling from a height. The patient's medical history was unremarkable except for coronary artery disease. He had not experienced pulmonary or allergic disorders in the past. Physical examination and laboratory values were unremarkable. Lung examination showed equal respiration in both lungs. Respiratory sounds were normal. Physical examination showed edema and ecchymosis in the frontal region and tenderness in the nose and maxillary region. Laboratory test results at initial admission were within normal limits. Computed tomography (CT) of the brain showed a frontal sinus fracture line. Chest CT incidentally revealed an azygos fissure along with an azygos lobe on the right side (Figure 1). The patient was hospitalized in the neurosurgery department for follow-up and treatment. 


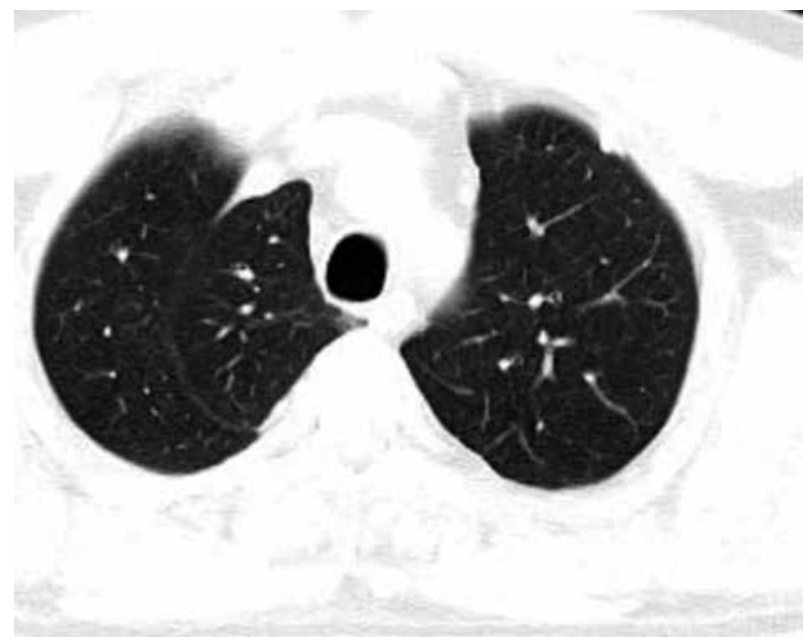

Figure 1. Thoracic computed tomography showing azygos lobe in axial section.

\section{DISCUSSION}

Azygos lobe is a rare anatomical variation located in the upper mediastinum. Segments occur independently and occur as lobes. The azygos lobe may be located behind the superior vena cava and trachea, and may be in proximity of the descending aorta and medial wall of the esophagus. ${ }^{[6]}$ It is more common in males and has genetic predisposition. It often occurs in the right lung. ${ }^{[1,2]}$ In our study, it had similar demographic characteristics and was located in the right lung.

Although the azygos lobe can be detected in chest X-ray, CT can be used in some cases. Incidence is $1 \%$ in chest X-ray and $1.2 \%$ in CT. ${ }^{[2,7]}$ Our case was detected incidentally in CT. Similar to our case, a convex line due to azygos fissure resembles a triangular-shaped area (trigon) attached to the extrapleural tissue on the fissure and the lower part of the azygos vein. ${ }^{[1]}$

The appearance of the azygos lobe is classified in three forms in relation to the lung apex. Type A in the lateral of the trigon apex, fissure vertically located in type $\mathrm{B}$, in type $\mathrm{C}$, the fissure is medial and extending to the mediastinum. ${ }^{[3]}$ In our patient, the azygos lobe was type $\mathrm{B}$.

Although the azygos lobe is rarely encountered, it may be associated with pathologies such as malignancies, pneumothorax, hemothorax, extrapulmonary sequestration, and vascular malformations. ${ }^{[8]}$ In a previous study, a patient with azygos lobe accompanied by pneumothorax underwent operation and the azygos vein was the initial target. ${ }^{[9]}$

An azygos lobe is often incidentally detected in imaging studies when investigating an unrelated pathology. Radiologic identification is important and azygos lobe should be considered in the differential diagnosis of possible problems during lung surgery and its similarity to other pathologies of the lung. ${ }^{[10]}$

In conclusion, although they are rarely seen in chest X-ray or tomography fatigue, physicians should consider azygos lobe among the differential diagnoses of lung pathologies.

\section{Declaration of conflicting interests}

The authors declared no conflicts of interest with respect to the authorship and/or publication of this article.

\section{Funding}

The authors received no financial support for the research and/or authorship of this article.

\section{REFERENCES}

1. Ariyürek OM, Gülsün M, Demirkazik FB. Accessory fissures of the lung: evaluation by high-resolution computed tomography. Eur Radiol 2001;11:2449-53.

2. Aziz A, Ashizawa K, Nagaoki K, Hayashi K. High resolution $\mathrm{CT}$ anatomy of the pulmonary fissures. $\mathrm{J}$ Thorac Imaging 2004;19:186-91.

3. Aypak C, Turedi O, Dicle M, Yuce A, Gorpelioglu S. A congenital abnormality could be detected on chest X-ray: Azygos lobe. Med Bull Haseki 2012;50:150-2.

4. Bedel C, Özkaya M. Diagnosis and prognosis of traumatic pulmonary pseudocysts. Indian J Thoracic Cardiovasc Surg 2018;35:186-9.

5. Bedel C, Türkoğlu S. A Rare Case of Tracheobronchial Anomaly: Tracheal Bronchus. Case Reports in Clinical Practice 2018;3:63-4.

6. Özdemir L, Özdemir B, Duman T. Prevalence of an azygos lobe using thoracic computed tomography. Cyprus J Med Sci 2016;1:55-7.

7. Rauf A, Rauf WU, Navsa N, Ashraf KT. Azygos lobe in a South African cadaveric population. Clin Anat 2012;25:386-90.

8. Gürkök $S$, Gözübüyük $A$, Yücel $\mathrm{O}$, Çaylak $\mathrm{H}$, Dakak M. Büllöz azigos lob: olgu sunumu. Türk Göğüs Kalp Damar Cerrahisi Dergisi 2007;15:168-9.

9. Monaco $\mathrm{M}$, Barone $\mathrm{M}$, Barresi $\mathrm{P}$, Carditello $\mathrm{A}$, Pavia R, Mondello B. Azygos lobe and spontaneous pneumothorax. G Chir 2000;21:457-8. [Abstract]

10. Kotov G, Dimitrova IN, Iliev A, Groudeva V. A Rare Case of an Azygos Lobe in the Right Lung of a 40-year-old Male. Cureus 2018;10:2780. 